\title{
Andean Root and Tuber Crops: Underground Rainbows
}

\author{
Hector E. Flores ${ }^{1,2}$ \\ Department of Plant Pathology and Biotechnology Institute, The Pennsylvania State University, University Park, \\ PA 16802 \\ Travis S. Walker ${ }^{1}$ \\ Department of Horticulture and Landscape Architecture, Colorado State University, Fort Collins, CO 80526 \\ Rejane L. Guimarães \\ Department of Plant Pathology and Biotechnology Institute, The Pennsylvania State University, University Park, \\ PA 16802 \\ Harsh Pal Bais and Jorge M. Vivanco ${ }^{2}$ \\ Department of Horticulture and Landscape Architecture, Colorado State University, Fort Collins, CO 80526
}

Additional index words. achira, Canna edulis, maca, Lepidium meyenii, mashua, Tropaeolum tuberosum, mauka, Mirabilis expansa, oca, Oxalis tuberosa, potato, Solanum tuberosum, ulluco, Ullucus tuberosus

\begin{abstract}
The Andean region is recognized today as one of the most important centers of crop origin and diversity in the world (National Research Council, 1989). Many of our most important food crops worldwide, most notably potatoes, were domesticated in this system (National Research Council, 1989). A unique feature of the Andean agricultural system is a taxonomically diverse group of Andean root and tuber crops (ARTC), coupled to the commonly found complement of grains and legumes, such as maize (Zea mays L.), chenopodium, beans, and lupines. The ARTC played a vital role in allowing sustained intensive cultivation and nourishment of a population that reached 10-12 million people at the height of the Incan Empire (1450-1535 A.D.) (King, 1987). About 17 species of root and tuber crops were domesticated in the Andes, making this the largest known geographical concentration of underground crops (Hernandez-Bermejo and Leon, 1992; Tapia, 1993).
\end{abstract}

The ARTC evolved in extremely inhospitable areas for agriculture, and Pre-Columbian people made extremely efficient use of what by today's agricultural standards would be considered marginal land (King, 1987). The steep slopes of the Andes are prone to constant erosion, extreme fluctuations in rainfall and temperature, and contain relatively poor soils. Crops grown in this environment were selected for their ability to cope with long periods of drought, freezing temperatures, and high UV irradiation. The Andean farmers took advantage of natural plant adaptations to extreme environments to domesticate a unique cohort of crops, and combined their cultivation with the use of complex irrigation canals, crop rota-

Received for publication 2 June 2002. Accepted for publication 8 Sept. 2002. Work reported in this review was supported in part by the McKnight Foundation to HEF, and grants from the National Science Foundation (MCB-0093014), the Colorado State Univ. Agriculture Experiment Station, the San Luis Valley Research Center Committee, and the Charles A. and Anne Morrow Lindbergh Foundation to J.M.V. ${ }^{1}$ Authors contributed equally to this work.

${ }^{2}$ To whom reprint requests should be addressed; e-mail: jvivanco@lamar.colostate.edu or hef1@psu.edu tions, inter-cropping techniques, and soil preservation practices (Flores and Flores, 1997). Underground storage organs are among the most common and efficient structures evolved by plants for survival in challenging environments. Root and tuber crops can also exhibit some of the highest yields for calories produced per area of cultivation; thus their adaptation and diversification in the Andes made both ecological and economic sense.

The ARTC today are common staples for an estimated 25 million people in the Andean highlands, and are at least an occasional food source for another 100 million people in Ecuador, Colombia, Peru, Bolivia, Argentina, and Chile. The traditional agricultural system of the Andes faces many challenges and uncertainties. Therefore, the need for promoting and preserving ARTC is immediate such that studies are necessary to improve pest management and crop productivity to motivate farmers towards the cultivation of these crops. Furthermore, the susceptibility of some of the more important ARTC such as mashua and ulluco to viral diseases warrants the need to provide disease-free accessions to minimize annual crop losses due to disease. The potential uses of the Andean root and tuber crops are discussed in this paper as we review their biology and biochemistry.

\section{THE ANDEAN ROOT AND TUBER CROPS}

The ARTC span no fewer than nine plant families: Asteraceae, Basellaceae, Brassicaceae, Leguminosae, Nyctaginaceae, Oxalidaceae, Solanaceae, Tropaeolaceae, and Umbelliferae. The genetic diversity and potential of these species is remarkable. Large germplasm collections are available for the three major tuber crops, oca, mashua, and ulluco, with $\approx 8000$ accessions combined. Thus, substantial ARTC biodiversity still persists in situ and ex situ. Oca, ulluco, and mashua alone could significantly expand the range of nutritional properties represented in the commonly cultivated and consumed Solanum sp. The ARTC represent a vast and mostly untapped pool of variation in type and content of starch, amino acid composition, other nutritional factors, and natural pesticides. The great adaptability of the ARTC favors their potential cultivation outside their area of origin. For example, oca is currently grown in Australia and New Zealand (National Research Council, 1989), while other species have recently been introduced to Mexico, Central America, Brazil, Europe, and Australia.

\section{Tuber crops}

Oca (Oxalis tuberosa, Oxalidaceae). After potato, oca is the most common tuber crop in the Andean region (Pulgar-Vidal, 1981). Oca is a prostrate herb with a compact growth habit of $\approx 20-30 \mathrm{~cm}$ in height with cylindrical succulent stems varying in color from green to red (Fig. 1), and the tubers range from cylindrical to ovoid, averaging 7 to $11 \mathrm{~cm}$ in length. The texture of the tuber skin varies from smooth to rough, and the color is white, yellow, pink, red, purple, or black (Seminario, 1988). Oca is widely adapted to divergent environments, and it is commonly cultivated in areas with elevations between 2800 and $4000 \mathrm{~m}$ and a range of precipitation of $570-2500 \mathrm{~mm}$ (Seminario, 1988). It grows in moderately cool temperatures down to $5{ }^{\circ} \mathrm{C}$, and poor soil conditions with a $\mathrm{pH}$ range of 5.3-7.8 (Leon, 1964; Seminario, 1988). This crop is grown in greatest abundance in the highlands of Ecuador, Peru, and Bolivia, but is also found in regions of Chile, Argentina, Colombia, and Venezuela. Oca has been commercialized in New Zealand, Australia, Mexico, France, and Great Britain either as a food staple or as a home-garden ornamental (King and Gershoff, 1987; National Research Council, 1989).

Evidence suggests that the cultivated oca is an octoploid species, $2 n=8 x=64$ chromosomes (Arbizu and Tapia, 1994). For practical purposes, the crop is sterile and thus maintained vegetatively. The ex-situ oca germplasm is distributed amid several genebanks in South America, with 482 accessions cataloged at the International Potato Center-Peru (CIP), 1696 at Instituto Nacional de Investigacion Agropecuaria-Peru(INIA), 912 at Universidad Nacional San Antonio-Peru (UNSAAC), 680 at Instituto Boliviano de Technologia Agropecuaria-Bolivia (IBTA). However, Andean 

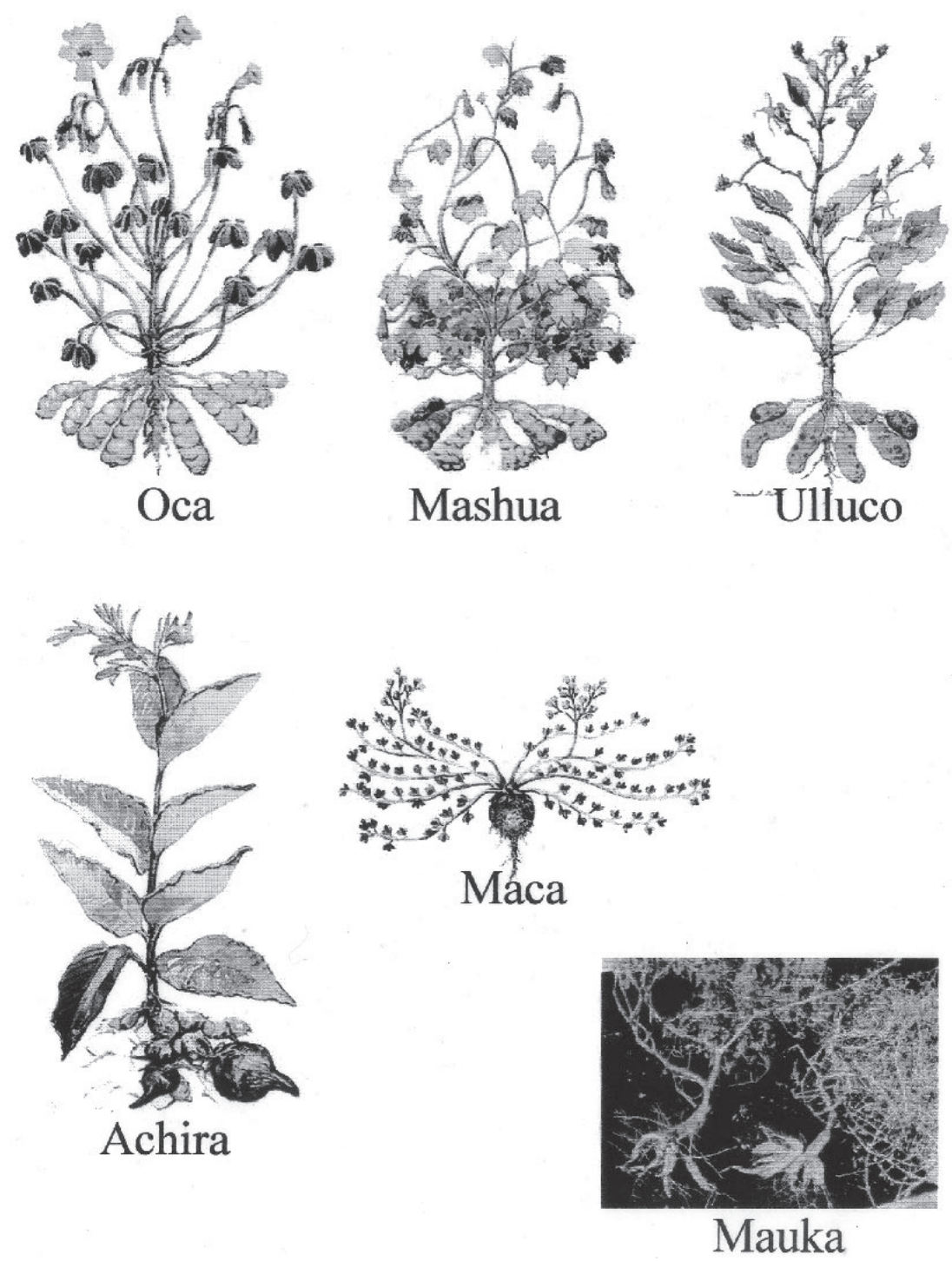

Fig. 1. Images of plants of the six Andean root and tuber crops showing both aboveground foliage and belowground storage organs.

Table 1. Nutritional values of the major Andean tuber crops in parts per million (ppm dry-weight basis). ${ }^{\mathrm{z}}$

\begin{tabular}{lcccc}
\hline Nutritional facts & Mashua & Oc Oca & Ulluco & Potato \\
\hline Ascorbic acid & $670-4800$ & $370-2284$ & $230-1750$ & $170-990$ \\
Calcium & $70-500$ & $40-247$ & $30-365$ & $34-2550$ \\
Carbohydrate & $59-786$ & $138-852$ & $118-912$ & $171-862$ \\
Fat & $2-42.8$ & $6-37.0$ & $2-14.6$ & $1-9.0$ \\
Fiber & $6-57.0$ & $5-49.0$ & $3-44.0$ & $3-27.0$ \\
Iron & $2-85.0$ & $8-49.0$ & $7-58.0$ & $5-128.0$ \\
Phosphorus & $13-115.0$ & $340-2099$ & $340-2775$ & $320-4200$ \\
Protein & $220-3000$ & $7-62.0$ & $10-73.0$ & $10-127.0$ \\
Riboflavin & $0.8-8.5$ & $0.3-4.3$ & $0.2-2.2$ & $0.4-1.9$ \\
Thiamine & $0.6-9.3$ & $0.5-3.1$ & $0.4-4.3$ & $1-5.0$ \\
Kilocalories & --- & $630-3890$ & $500-3725$ & $780-3755$ \\
$\beta$-carotene & $0.3-2.1$ & 0.2 & 0.7 & 1.0 \\
\hline
\end{tabular}

${ }^{\mathrm{z}}$ Data from the Agriculture Research Services Dr. Duke phytochemical and ethnobotanical database (http: //www.ars-grin.gov/duke).

farmers primarily maintain the biodiversity of oca through on-farm propagation (Arbizu, 2000; Arbizu et al., 1997), and only a small fraction of the total germplasm has been exploited by plant breeders to develop new cultivars (Hodge, 1985).

Oca tubers show high variability in nutritional levels between genotypes, and they are a good source of carbohydrates, calcium,
Mashua(Tropaeolum tuberosum, Tropeolaceae). Mashua is an herbaceous perennial plant, and a close relative of the garden nasturtium. The plant habit is prostrate or climbing and it grows over $1 \mathrm{~m}$ in diameter and $0.5 \mathrm{~m}$ in height, and produces slender leaves (Fig. 1). The tubers vary in color and shape. The tuber skin is white, yellow, or occasionally purplish or red. Some tubers are mottled or striped with red or purple, particularly below the "eyes," and as in potato and oca, small leaf scales border the deep-set "eyes." The flesh of the tuber is generally yellow irrespective of the morphotype (National Research Council, 1989). Mashua can be propagated vegetatively, but it also produces a large quantity of viable seed (Arbizu and Tapia, 1994).

Although mashua is grown from 2400 to $4300 \mathrm{~m}$, the best production of mashua tubers occurs at elevations around $3000 \mathrm{~m}$, with maximum yields of $30,000 \mathrm{~kg} \cdot \mathrm{ha}^{-1}$. Mashua is usually cultivated once a year because tuber formation occurs only during short photoperiods of $\approx 11-13.5 \mathrm{~h}$ of daylight. The life cycle of 5-6 months is relatively short compared with other root and tuber crops (National Research Council, 1989; Zela et al., 1997). Without traditional irrigation practices, mashua requires annual precipitation amounts between 700 and $1600 \mathrm{~mm}$, and the best soil type for this crop is a fertile, organic soil with $\mathrm{pH}$ values from 5.3 to 7.5 (Torres et al., 1992).

Mashua is cultivated in Argentina, Bolivia, Colombia, Ecuador, Peru, and Venezuela, and has recently been introduced to New Zealand. Andean farmers recognize a number of different mashua morphotypes based on color, form, and taste of the tubers. Domesticated mashua is thought to be comprised of more than 400 different morphotypes (Sperling and King, 1990). Mashua accessions in genebanks, distributed among different institutions around the Andean region, include 101 at Cuzco (Peru), 146 at Ayacucho(Peru), 125 at Universidad Nacional Mayor de San Marcos-Peru (UNMSM), 55 at Programa de Investigacion de Papa-Bolivia (PROIMPA), and 43 at Instituto Nacional de Investigacion Agropeciaria-Ecuador (INIAP). The majority of these accessions are maintained through in vitro propagation.

The Andean highlanders use mashua as a food crop and as a medicinal crop. All parts of the plant can be consumed, including the tubers, leaves, and blossoms, but the tuber is the most commonly consumed because of its flavor and nutritional value (National Research Council, 1989). Compared to other Andean root and tuber crops, mashua contains high levels of ascorbic acid (vitamin C), thiamin (vitamin B1), riboflavin (vitamin B2), as well as lipids (Table 1), and the tubers are relatively high in protein content and fiber. These nutritional characteristics make the mashua tuber an important component of an Andean highlander diet.

Ulluco (Ullucus tuberosus, Basellaceae). Ulluco is a low-growing herb with heartshaped succulent leaves, and morphotypes vary from prostrate, semiclimbing vines to dense and compact bushes (Fig. 1). Tubers can be elongated or curved, with a thin, soft 
skin and have inconspicuous buds. The color of the tubers can be white, pink, orange, magenta, red, or magenta spots mixed on a yellow background. Based on tuber appearance alone, about 70 distinct morphotypes have been reported (National Research Council, 1989; Sperling, 1987). As in the case of other Andean root and tuber crops, accessions have been maintained in several institutes; the International Potato Center alone holds $\approx 418$ accessions of ulluco. This crop is widely consumed in the highlands of Peru, reaching a yield of $88.57 \mathrm{t} \cdot \mathrm{ha}^{-1}$ in 1990 (King and Gershoff, 1987). Ulluco is cultivated at altitudes of $3000-3800 \mathrm{~m}$ in the central and south region of the Andes, including Peru, Bolivia, Ecuador, Colombia, Venezuela, and Chile; and this crop is virtually unknown outside the Andes (Vega, 1997).

The cultivated ulluco has a base chromosome number of $x=12$ and can be either diploid $(2 n=24)$ or triploid $(2 n=36)$. Triploids are always sterile and can be propagated only vegetatively, but in spite of this, they occur over a wider range than diploid types due to their adaptability (Arbizu and Tapia, 1994). Morphotypes differ in the time it takes to reach maturity, varying from 5-9 months and 10-13.5 h of daylight (Vega, 1997). Ulluco requires $700-800 \mathrm{~mm}$ of precipitation to sustain productive yield, but it is considered well adapted to dry conditions and slightly acidic soil (5.5 to 6.5) (Vega, 1997).

Ulluco tubers are an excellent source of protein, carbohydrates, and vitamin C (Busch et al., 2000) (Table 1). Because the tubers are rather perishable, Pre-Columbian people processed the tubers using an environmental freezing and drying process, which takes advantage of the day-night temperature differential during the dry period (May through September). The longlasting product of this process is called lingli or chuño, which is usually ground into flour and added to cooked foods. Similar "freeze-drying" processes have been used to preserve native potato, oca and mashua (National Research Council, 1989).

Achira (Canna edulis Cannaceae). Achira is a perennial monocotyledon closely related to the ornamental cannas grown in temperate and tropical zones. Achira grows up to $2.5 \mathrm{~m}$ high and produces rhizomes of $\approx 60 \mathrm{~cm}$ in length (Fig. 1). It is cultivated in the Andean region and in Mexico and the West Indies. In South America, achira is distributed from the Amazon basin through the Pacific coast to northern Chile and Argentina at altitudes ranging from 1000 to $2900 \mathrm{~m}$ (Flores and Flores, 1997; National Research Council, 1989). Compared to the other Andean tuber crops the biodiversity of achira is rather lacking; only 20 clones of achira for example have been maintained at CIP (International Potato Center, 1994). Cultivars vary in foliage color, stem height, rhizome size and coloration, and are propagated exclusively by vegetative means (Flores and Flores, 1997).

It is likely that achira originated in the tropics of South America (Ugent et al., 1984) and has long been domesticated and cultivated in Peru. Archeological remains of achira are found in Pre-Ceramic cultures in South America, dating back to 2250 вС (Ugent et al., 1984). Further evidence for the ancient use of achira rhizomes is found in the arts and crafts of the pre-Inca civilizations of Nasca and Chimú (Montaldo, 1977).

The rhizomes of achira are very rich in carbohydrates, containing $\approx 75 \%$ to $80 \%$ starch and $6 \%$ to $14 \%$ sugar, most of which is glucose and sucrose (National Research Council, 1989). Achira flour and starch are used for the production of specialty noodles and other products in South East Asian countries (International Potato Center, 1994).

\section{Root crops}

Maca (Lepidium meyenii,Brassicaceae). Maca, a member of the radish family, occupies a rather restricted ecological zone in central Peru at elevations of 3500 to $4500 \mathrm{~m}$ above sea level. Maca is possibly the only crop in the world capable of growing at such extreme elevations (Tello et al., 1992), and it has also gained some celebrity status due to its reputed fertility-enhancing properties, which have spawned a cottage industry of beverages and pills. Considered some of the poorest farmland in the world, the ecosystem where maca is cultivated is characterized by areas of barren, rocky terrain, intense sunlight, fierce winds, and freezing temperatures (Johns, 1981). Currently, <50 total ha of land are dedicated to the cultivation of maca in Peru, but due to its reported medicinal properties, the demand for this crop is increasing (Tello et al., 1992). There is evidence that in the past maca occupied a much wider area of cultivation(Johns, 1981); furthermore, Andean natives used maca as an item of exchange for payment of taxes to the Spanish Conquistadors (Castro de Leon, 1990).

The maca plant is a low-growing herbaceous perennial not exceeding 12 to $20 \mathrm{~cm}$ in height, and the plant is a rosette of frilly leaves with a fleshy underground taproot developed from the lower portion of hypocotyl (Leon, 1964; Tello et al., 1992) (Fig. 1). The expanded hypocotyls resemble a turnip in size and shape, between 2 and $5 \mathrm{~cm}$ in size, and can be many shades and combinations of white, yellow, gray, purple, and red (Tello et al., 1992). The aboveground foliage forms a dense mat with short decumbent stems growing close to the soil surface. Maca leaves display dimorphism, wherein the leaves are prominent in the vegetative stage and reduced to vestigial in the reproductive stage. The rosulate, pinnatipartite leaves are continually renewed from the center of the rosette (Tello et al., 1992).

Maca plants flourish at high elevations in the central Andes of Peru, a region where only highland grasses and a few hardy Solanaceae survive (Bonnier, 1986). In this habitat, frost is common and temperatures can drop as low as $-10^{\circ} \mathrm{C}$ (Tello et al., 1992). When climatic conditions are favorable, maca grows as an annual crop, completing its life cycle in one year (Quiros et al., 1996). However, it is generally regarded as a true biennial plant because it has a vegetative cycle that is followed by a reproductive phase in the following season
(Tello et al., 1992). Estimated fresh yields of hypocotyls harvested from May to July are 14.7 $\mathrm{t} \cdot \mathrm{ha}^{-1}$, resulting in nearly $4.4 \mathrm{t} \cdot \mathrm{ha}^{-1}$ of dried hypocotyls (Tello et al., 1992). Although highly regarded for its medicinal uses, maca is also valued for nutritional reasons. The dried hypocotyls are comparable in nutritive value to cereal grains such as maize, rice (Oryza sativa Linn.), and wheat (Triticum aestivum L.), and can be stored for several years. The major nutrients in this crop are calcium (258 $\mathrm{mg}$ ) and iron (15.4 mg) per $100 \mathrm{~g}$ fresh weight (National Research Council, 1989). The dried hypocotyls contain up to $59 \%$ carbohydrate, $10 \%$ protein, $8.5 \%$ fiber, $2.2 \%$ lipid, and are also rich in starch, glucosides, alkaloids, and tannins (Dini et al., 1994). Total protein content may fluctuate between $10 \%$ and $14 \%$ depending upon the variety and soil fertility.

Mauka (Mirabilis expansa, Nyctaginaceae). Mauka is a relatively disease-resistant root crop, whose historical importance is just now coming to light as it was rediscovered only a few years ago. In the early 1960s, the Bolivian scientist Julio Rea first described mauka as a vital food source of the Maukallajita Indians inhabiting the high valleys of La Paz, Bolivia (Rea and Leon, 1965). Fifteen years later, the cultivation of mauka was confirmed in the cold, dry regions north of Quito, Ecuador, and later reported in Cajamarca, Peru (National Research Council, 1989).

Mauka is a low compact herbaceous plant not exceeding $1 \mathrm{~m}$ in height, and is a relatively disease-resistant crop that produces edible storage roots (Franco and Vejarano, 1996) (Fig. 1). The cultivation of this crop has been restricted to three small regions in Peru, Ecuador and Bolivia (National Research Council, 1989), and it is believed to face strong genetic erosion. It grows well at high elevations (2200-3500 m) and at temperatures between $4^{\circ}$ and $29^{\circ} \mathrm{C}$ (Franco and Vejarano, 1996). The aerial portion is composed of a mass of edible foliage developing from the basal shoots. Mauka stems are cylindrical in shape with opposite, ovoid leaves that display reddish edges (Franco and Vejerano, 1996). The inflorescences are terminal racemes coated with viscid hairs that trap small insects, and the flower color varies with geographic location. Bolivian types develop uniform purple flowers, while Ecuadorian types are purple and white (National Research Council, 1989). The below ground storage roots are white, salmon-colored, or yellow with young tubers being yellow and older ones being white (Seminario and Seminario, 1995). Mature mauka roots can grow to the length and diameter of a human forearm (Seminario and Seminario, 1995). Although mauka has the enlarged stems and roots of a perennial, it is typically harvested as an annual but can remain in the field for extended periods of time. In traditional cultivation in the cold highlands above $3100 \mathrm{~m}$, the plant may require 1 year of growth to reach harvestable size. Normal yields from traditional farming practices are $\approx 20 \mathrm{t} \cdot \mathrm{ha}^{-1}$; however, after 2 years of cultivation, yields increase to nearly $50 \mathrm{t} \cdot \mathrm{ha}^{-1}$ (Franco and Vejerano, 1996; Hernandez-Bermejo and Leon, 1992). 
Mauka provides a wealth of edible stems and storage roots with a comparatively high protein and carbohydrate content. Mauka roots contain $\approx 87 \%$ carbohydrate on a dry weight basis (Montenegro and Franco, 1988; National Research Council, 1989) and accessions from Bolivia and Peru have 7\% and 5\% protein content, respectively (Hernandez-Bermejo and Leon, 1992). Similarly, the calcium levels in mauka roots are nearly $1000 \%$ higher than the other ARTC, although they occur as calcium oxalate raphides in root cortex cells for the most part and thus are nutritionally unavailable. The calcium levels vary from 157 to $461 \mathrm{mg}$ per $100 \mathrm{~g}$ of dry weight (Montenegro and Franco, 1988). Phosphorus levels are also elevated compared to the other ARTC; however, sodium and iron levels are low in mauka. The leaves contain $\approx 17 \%$ protein with a higher level of digestibility than other forages cultivated in the Andean highlands (National Research Council, 1989).

\section{Medicinal applications of ARTC}

The ARTC have recently gained worldwide interest due to their purported medicinal properties for humans. For centuries, plants have been used by civilizations for medicinal purposes. Roots from several plants have been used as sedatives, stimulants, antihelminthics, and antimicrobials, including mandrake (Mandragora officinalis L.), ginseng (Panax ginseng L., P. quinquefolium L.), ipecac (Cephalis ipecachuana Brot.), and valerian (Valeriana officinalis L.) (Foster and Duke, 1990). Similarly, many of the ARTC have been employed by the natives of the Andean region to ease labor pains, treat kidney ailments, and to increase and/or decrease fertility and libido in males and females.

According to the common folklore of the Andean highlands, maca is an aphrodisiac that improves sexual drive and female fertility, both of which are often impaired at high elevations (Leon, 1964). During the conquest of the Incan Empire, the Spaniards fed maca to their soldiers, horses, chickens, and pigs to enhance their energy and vitality and to improve the reproductive capabilities of the domesticated animals at high elevations (Sanchez Leon, 1996). Recent clinical studies with rats (Cicero et al., 2001, 2002) and adult men (Gonzalez et al., 2001) have supported the fertility-enhancing properties of maca. The reported gains in female fertility are likely due to an increase in the development of Graafian follicles, the fluid-filled vesicles of the mammalian ovary containing maturing ova (Chacon, 1990; Rea, 1992). Nutraceutical companies in the U.S. now market maca in pill form as a supplement reputed to enhance stamina and fertility, but as for many such products there is a wide variation in quality control. Chemical analysis of maca indicates that the fertility-enhancing properties may be attributed to the presence of biologically active aromatic isothiocyanates, in particular benzyl isothiocyanate and p-methoxybenzyl isothiocyanate (Johns, 1981), or possibly due to the existence of prostaglandin-like compounds and phytosterols in the hypocotyls (Dini et al., 1994).
The domestication of mashua also has been associated with its numerous medicinal uses in the folk medicine of the Andean region (Johns et al., 1982). Mashua is considered an antiaphrodisiac, believed to cause impotence and infertility in males. Experimental studies on male rats that were fed a diet of mashua tubers showed a $45 \%$ decrease in testosterone/ dihydrotestosterone levels (Johns et al., 1982). In females, mashua is proposed to increase fertility due to $N, N$-di-(methoxy-4-benzyl) thiourea contained in the tubers, a compound that competitively inhibits estradiol binding and increases estrogenic activity (Johns et al., 1982). Mashua tubers have been reported in Andean folk medicine as an antibiotic and diuretic and have been used to remedy multiple kidney ailments and diseases, as well as to eliminate bladder and kidney stones (Johns et al., 1982). In modern medicinal practices in Bolivia, mashua is employed as an emmenagogue, and is thought to stimulate menstruation (Johns et al., 1982). Many of the reported medicinal properties of mashua experimentally appear to result mainly from p-methoxybenzyl isothiocyanate (Johns and Towers, 1981). The reported antibiotic, anticancer, and diuretic properties of isothiocyanates support the many uses of mashua in Andean folk medicine (Fahey et al., 1997; Johns et al., 1982; Talalay and Fahey, 2001).

Ulluco in the highlands is used in medicinal applications for pregnant Andean women. Women consume ulluco to ease pain during pregnancy, and the severity of labor pains during childbirth (National Research Council, 1989), but no scientific research has been conducted to identify the bioactive principles. Additionally, little is known about the medicinal properties of mauka and oca; however, Mirabilis species native to the American Southwest have been utilized by the Hopi Indians in North America for medicinal purposes (Moore, 1988; Seminario and Seminario, 1995).

\section{ETHNOBOTANICAL CONNECTIONS}

Andean farmers developed a sophisticated repertoire of practices to cope with rugged planting terrain, diverse environmental conditions, and indigenous diseases, which create an ongoing challenge to grow and maintain successful plots of ARTC each year. The severely sloping and eroding mountain slopes posed a serious challenge to the area's agriculture. To alleviate the problem of soil erosion and to provide suitable growing plots, the ancient Andean farmers constructed elaborate terraces across the steep slopes, perched one above another along the mountainsides (Fig. 2). The highlands of Peru contain nearly 60,000 ha of terraced farmland, and tubers such as oca, potato, ulluco, and mashua are still planted in some of these plots today (National Research Council, 1989).

The environmental conditions in the highlands of Peru are perhaps the most extreme and varied in the world. For instance, at the base of a single terraced slope, moderate to hot temperatures and accompanying rainfall may prevail, while near the summit cold temperatures and frost predominate (Fig. 2). Andean farmers utilized knowledge of these microclimates to protect against crop failure, understanding that crop or variety adaptation may be different at each elevation. Vertically diversified farming practices encouraged the development and planting of several different crop varieties, each with slightly different tolerances to temperature, moisture, soil type, and other factors (National Research Council, 1989). The rationale for these practices is that they served as a form of insurance in the event that one or more morphotypes failed, and the different growth cycles at differing elevations allowed the work to be staggered over a longer period of time, which permitted more land area to be cultivated (National Research Council, 1989).

In any farming system, disease and pests represent serious threats to valuable ARTC in the Andean highlands, but unlike modern agricultural practices that utilize chemically derived herbicides and pesticides, Andean farmers rely on intercropping to control disease and pests. In a single field, an Andean farmer may grow up to 200 different kinds of potatoes (Flores and Flores, 1997). In the highlands, through generations of farmer-based knowledge of mashua's disease and pest resistance, farmers have continually planted mashua in field plots with oca, potatoes, and ulluco to manage disease and pests (Fig. 3) (National Research Council, 1989). Studies by Johns et al. (1982) have shown that mashua tubers are resistant to an array of bacteria, fungi, nematodes, and insects such as the Andean weevil, a finding which validates the importance of mashua as an intercropping species throughout generations of Andean farming practices.

\section{BIOCHEMISTRY AND BIOTECHNOLOGY OF ANDEAN ROOT AND TUBER CROPS}

In recent years, underground storage organs have been studied in an attempt to understand the functional link between underground processes and aboveground mechanism. Apart from the classical role of providing mechanical support and nutrient uptake, roots and tubers also perform specialized roles as chemical factories that can synthesize, store, and secrete a diverse array of biologically active compounds such as proteins and low-molecular-weight secondary metabolites (Flores et al., 1999).

Plant callus, cell suspension, and root cultures are systems amenable for the largescale production of pharmaceutical enzymes (Flores et al., 1999) and offer a viable method for the production of antimicrobial proteins. Agrobacterium-transformed root cultures of mashua have been established, and root cultures showed the presence of the $58 \mathrm{kDa} \beta-1,3$-glucanase-related protein found in mashua tubers. Addition of jasmonate and salicylic acid to the culture medium elicited increased levels of this protein (Guimarães, 2001). Similar results were found with MEC, an RIP purified from $M$. expansa cell cultures (Vivanco and Flores, 2000). We have recently established 


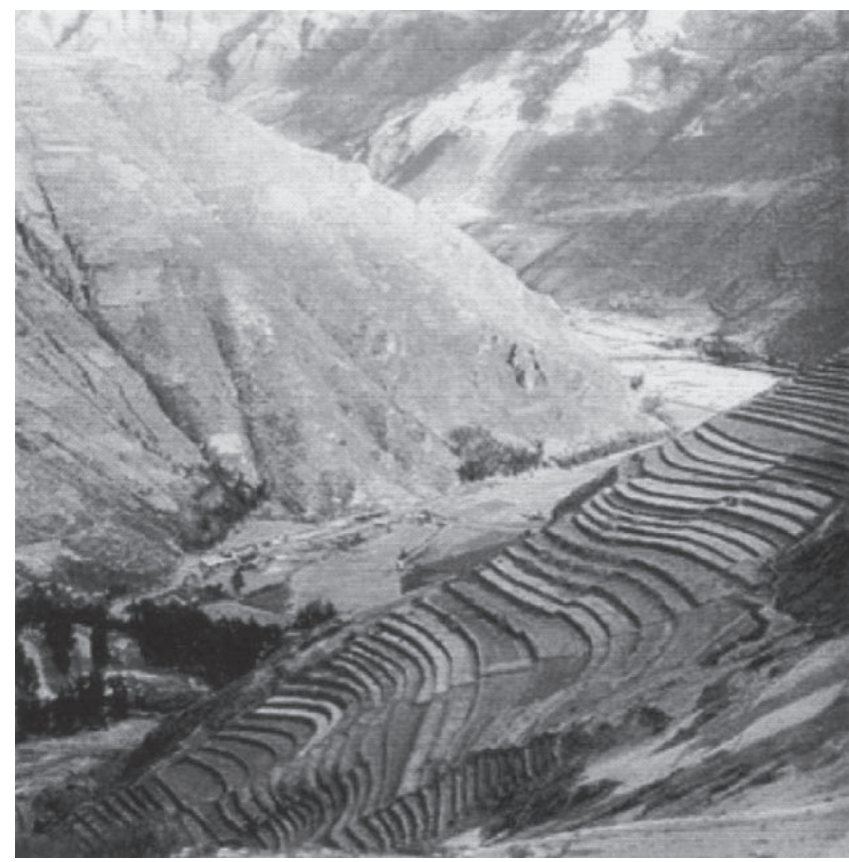

Fig. 2. Ancient terraced slope with small field plots in the Andean Mountains.

Agrobacterium-transformed hairy root cultures of oca and ulluco, which may provide insights about the significance of biologically active proteins and phytochemicals from the roots of these two crops.

A protein of $18 \mathrm{kDa}$ present in all oca morphotypes, was found to be the most abundant protein in oca tubers $(20 \%$ to $40 \%$ of total soluble tuber protein) (Flores, 1999; Flores et al., 2002). This protein, ocatin, appears to be a tuber-specific protein localized in the parenchyma cells of the pith and the peridermis, representing a good source of amino acids for the tuber. In addition to its storage role, ocatin is very active against the following fungal pathogens: Rhizoctonia solani, Phytophthora cinnamomi, Fusarium oxysporum, and Nectria haematococcus. Anti-bacterial activity was also found against Agrobacterium tumefaciens, A. radiobacter, Serratia marcescens, and Pseudomonas aereofaciens, and the gene encoding ocatin was isolated and observed to have high homology with pathogenesis-related (PR) proteins found in a wide variety of species (Flores et al., 2002).

Antimicrobial proteins were also purified from tubers of mashua (Guimarães, 2001). These proteins, a $\beta$-1,3-glucanase $(32 \mathrm{kDa})$ and an osmotin-like protein $(22 \mathrm{kDa})$, acted synergistically to inhibit the growth and spore formation of Trichoderma harzianum; however, unlike ocatin, these two proteins are present in relatively small amounts and are restricted to select morphotypes (Guimarães, 2001). A polyclonal antibody raised against the glucanase cross-reacted with a related protein of about $58 \mathrm{kDa}$ found mainly in the cell walls of roots (Guimarães, 2001).

Two novel type I Ribosome Inactivating Proteins (RIP), designated ME1 and ME2, of 27 and $27.5 \mathrm{kDa}$, respectively, were purified from the storage roots of the mauka (Mirabilis expansa) (Vivanco et al., 1999b). The proteins (Tropaeolum tuberosu) (background). showed additive antifungal activity against several fungi, including Pythium irregulare, Fusarium oxysporum, and Trichoderma harzianum. Antibacterial activity in both ME1 and ME2 was observed against Pseudomonas syringae, Agrobacterium tumefaciens, Agrobacterium radiobacter, and others. In addition to the antifungal and antimicrobial activities of ME1 and ME2, antiviral activity has also been confirmed for these proteins. Preventive applications of ME1 and ME2 on Gomphena globosa L. leaves inhibited mechanical infection by potato virus X (Vivanco et al., 1999a), suggesting a broad-spectrum defense function. The two proteins are localized in cell wall and parenchyma tissue of storage roots, and similar proteins were found in roots of other Mirabilis species, indicating the two proteins are genus-specific (Vivanco and Flores, 2000). The potential applications for the aforementioned findings are extensive, since these proteins can possibly be used as antimicrobial agents in transgenically modified crops or in simple crop protection methods in low input agricultural systems, such as spraying root extracts on leaves of various crops to prevent or control pathogen infection.

Andean root and tuber crops are not only a novel source of antimicrobial proteins, but of secondary metabolites as well. For instance, we recently characterized a fluorescent secondary metabolite in the root exudates of oca (Bais et al., 2002). The main fluorescent compound from oca's root exudates was identified as harmine (7-methoxy-1-methyl- $\beta$-carboline), a widespread photoactive $\beta$-carboline with reported light-mediated activity against bacteria and insects (Larson et al., 1988). Harmine exhibits a strong purplish-blue fluorescence, which correlates to the fluorescence observed in oca's medium (Bais et al., 2002). As discussed above, mashua is known to contain glucosinolates such as 4-methoxybenzyl-glucosinolate as the predominant glucosinolate (Johns, 1981). In some morphotypes, we have found that benzyl- and 4-methoxybenzyl-glucosinolates are the predominant forms of glucosinolates present in the plant, while traces of other glucosinolates may be found as well (Guimarães, 2001). The underground glucosinolates pattern also varies; tubers of mashua contain mainly 4-methoxybenzyl-glucosinolates and traces of 2-phenylethyl- and 2-hydroxy-2-phenylethylglucosinolates. Mashua hairy roots produced glucosinolates in both the roots and the exudates (Guimarães, 2001). Benzylisothiocyanate, the product of glucosinolate degradation by myrosinase, is active against a range of tumor cells (Hasegawa et al., 1992; Pintão et al., 1995). Production of benzylisothiocyanates using hairy root cultures has been achieved, and large-scale production seems highly feasible (Wielanek and Urbanek, 1999).

Traits of the Andean cultivated potatoes such as resistance to frost, virus, nematodes, and bacteria are appealing to breeders, and

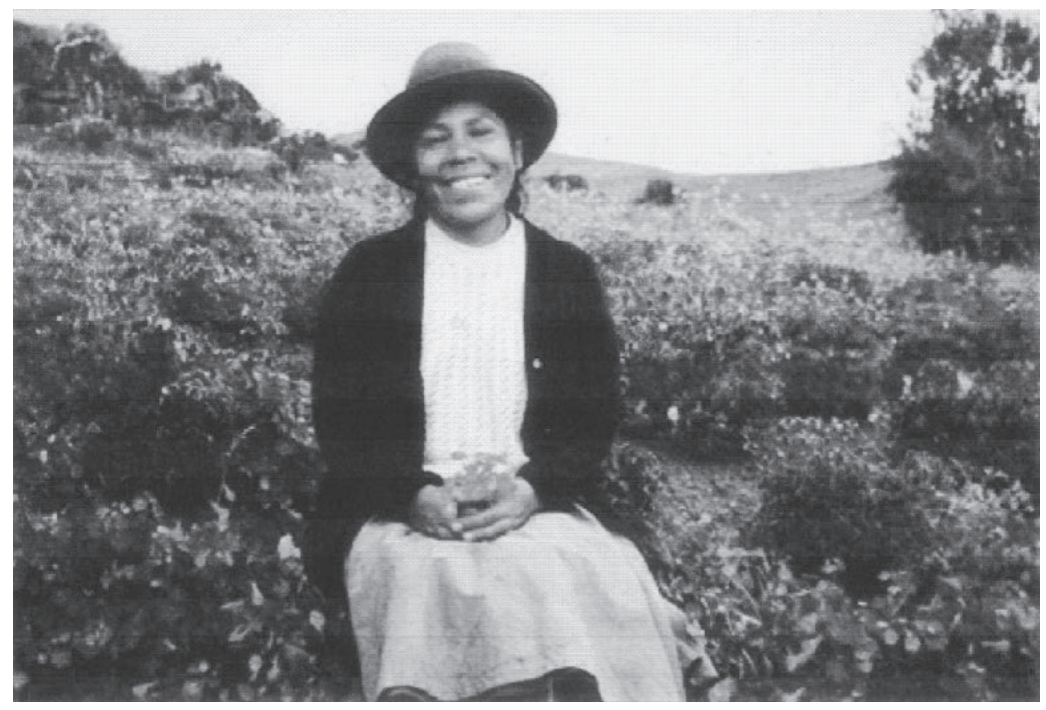

Fig. 3. Local Andean farmer in a field intercropped with oca (Oxalis tuberosa) (foreground) and mashua 
some of these properties are associated with the glycoalkaloid content. Potent molluscicidal activity was found in roots of Canna indica $\mathrm{L}$., but the actual compound causing it has not yet been identified (Tripathi and Singh, 2000). Saponins of ulluco and glucosinolates of maca may be associated with disease resistance (Flores and Flores, 1997). Franco et al. (1999) reported that some morphotypes of ulluco, mashua, and oca inhibited the egg hatching of cyst nematodes, but again further studies are need to identify the active compounds.

\section{CONCLUSION}

The ARTC are a fascinating set of crops adapted to the extreme conditions of the Andean region. The six Andean tuber and root crops described and discussed in this review have been cultivated in the Andean region for centuries and continue to be important food crops in South American countries. They are a good source of nutrition and have strong aesthetic appeal due to their wide variation in form and color. Many of the diverse varieties of these species have been collected and are available for research and breeding purposes (Condesan-CIP, 1997). One of the species, Oxalis tuberosa, has spread to Mexico and New Zealand where it is marketed and consumed in numerous dishes. Oca is currently being imported to the United States from New Zealand in increasing amounts (http://www.friedas.com/ detail.cfm? id=192). Another ARTC, ulluco, is now processed in Australia and exported to the United States.

The potential for introducing several ARTC as food crops for other areas of the world is significant. Recently, there has been an effort to select adapted clones for trials in other regions of the world. These efforts are aimed at increasing the crop options available to farmers, increasing the diversity of food sources, and developing crops for marginal growing regions. Suitable areas include highaltitude regions in low latitudes and oceanic or insular climates with long, cool growing seasons. In mild climates of the southern and northern hemispheres, the ARTC could be grown as alternative winter crops. Proper selection of germplasm adapted to specific environments will determine the successful introduction of the ARTC. Factors such as the short days required for tuber formation may limit potential production areas; thus, there is a need for photoperiod-insensitive varieties. Steps taken to strengthen the biotechnological knowledge related to these root and tuber crops are commendable, although further effort is required to exploit their phytochemical and pharmacological properties. Finally, the commitment of international research to the ARTC will not only aid in the introduction of these crops to other global regions, but will enhance the current production of these crops in their native Andean region.

\section{Literature Cited}

Agricultural Research Service. Dr. Duke's phytochemical and ethnobotanical database. Cited from the World Wide Web 6 Jun. 2000. http://www.ars-grin.gov/duke

Arbizu, C. 2000. Relationship between in situ and ex situ conservation, p. 13. In: Effectivity of in situ conservation strategies and peasants'knowledge on the use of biodiversity. Copacabana, Bolivia (Abstr., in Spanish).

Arbizu, C., A. Golmirzaie, and Z. Huamán. 1997. Other Andean roots and tubers, p. 39-56. In: D. Fuccillio, L. Sears, and P. Stapleton (eds.). Biodiversity in thrust: Conservation and use of plant genetic resources in CGIAR Centers. Cambridge University Press, Cambridge, U.K.

Arbizu, C. and M. Tapia. 1994. Neglected crops, p. 149-163. In: J.E. Hernándo Bermejo and J. León (eds.). Plant Production and Protection Series No. 26. FAO, Rome, Italy.

Bais, H.P., S.W. Park, F.R. Stermitz, K.M. Halligan, and J.M. Vivanco. 2002. Exudation of fluorescent $\beta$-carbolines from Oxalis tuberosa $\mathrm{L}$. roots. Phytochemistry. (In press.)

Bonnier,E. 1986. Utilisation du sol al'époque prehispanique: Le cas archeologique du Shaka ShakaPlacamayo. Cah. Sci. Hum. 22(1):97-113.

Busch, J.M., C. Sangketkit, G.P. Savage, R.J. Martin, S. Halloy, and B. Deo. 2000. Nutritional analysis and sensory evaluation of ulluco ( $U l$ lucus tuberosus Loz) grown in New Zealand. 80:2232-2240.

Castro de Leon, M. 1990. Un cultivo Andino en extinction: El caso de la maca. Peru Indig. 12: 85-94.

Chacon, G. 1990. La maca (Lepidium peruvianurn) Chacon sp. nov.) y su habitat. Rev. Peruana de Biologia 3:171-272.

Cicero, A.F., E. Bandieri, and R. Arletti. 2001. Lepidium meyenii Walp. improves sexual behavior in male rats independently from its action on spontaneous locomotor activity. J. Ethnopharmacol. 75(2-3):225-229.

Cicero A.F., S. Piacente, A. Plaza, E. Sala, R. Arletti, and C. Pizza. 2002. Hexanic Maca extract improves rat sexual performance more effectively than methanolic and chloroformic Maca extracts. Andrologia. 34:177-179.

Condesan-CIP. 1997. Andean root and tuber crops: A report on collaborative research in biodiversity, 1993-1997. Intl. Potato Center, Lima, Peru.

Dini, A., G. Migliuolo, L. Rastrelli, P. Saturnino, and O. Schettino. 1994. Chemical composistion of Lepidium meyenii. Food Chem. 49: 347-349.

Fahey, J.W., Y.Zhang, and P. Talalay. 1997. Broccoli sprouts: an exceptionally rich source of inducers of enzymes that protect against chemical carcinogens. Proc. Natl. Acad. Sci. USA 94: 10367-10372.

Flores, H.E. and T. Flores. 1997. Biochemistry of plant storage organs. Rec. Adv. Phytochem. 31: $113-132$.

Flores, T. 1999. Study on the tuber proteins from the Andean tuber crop Oxalis tuberosa M. (OCA). PhDThesis, The Pennsylvania State Univ., Dept. of Plant Pathology, University Park.

Flores, H.E., J.M. Vivanco, and V.M. Loyola-Vargas. 1999. Radicle biochemistry: The biology of root-specific metabolism. Trends Plant Sci. 4:220-226.

Flores, T., A. Alape-Girón, M. Flores-Díaz, and H. E. Flores. 2002. Ocatin. A novel tuber storage protein from the Andean tuber crop Oca with antibacterial and antifungal activities. Plant Physiol. 128:1291-1302.

Foster, S. and J.A. Duke. 1990. Eastern/Central medicinal plants. Houghton Mifflin, Boston.

Franco, S. and J. Vejarano. 1996. El chago o yuca inca (Mirabilis expansa) raiz andian en peligro de extincion. Instituto Nacional de Investigacion Agraria, Cajamarca-Peru.

Franco, J., G. Main, and R. Oros. 1999. Trap crops as a component for the integrated management of globodera spp. (potato cyst nematodes) in Bolivia. Nematropica 29:51-60.

Gonzalez, G.F., A. Cordova, C. Gonzales, A. Chung, K. Vega, and A. Villena. 2001. Lepidium meyenii (Maca) improved semen parameters in adult men. Asian J. Andrology 3:301-303.

Guimarães, R.L. 2001. Studies on the biology and biochemistry of Tropaeolum tuberosum (Mashua). PhD Thesis, The Pennsylvania State Univ,. Dept. of Plant Pathology, University Park.

Hasegawa, T., H. Nishino, and A. Iwashima. 1992. Isothiocyanates inhibit cell cycle progression of $\mathrm{HeLa}$ cells at $\mathrm{G} \operatorname{sub}(2) / \mathrm{M}$ phase. Anti-CancerDrugs 4:273-279.

Hernandez-Bermejo, J.E. and J.Leon. 1992. Cultivos marginados: Otra perspectiva de 1492, p. 39. In: Organizacion de las Naciones Unidas para la Agricultura y la Alimentacion, Roma.

Hodge, W.H. 1985. Three native tuber foods of the High Andes. Econ. Bot. 3:185-201.

International Potato Center Annual Report. 1994. Lost Andean roots and tubers travel ancient trade routes. Lima, Peru.

Johns, T. 1981. The añu and the maca. J. Ethnobiol. 1(2):208-212.

Johns, T., W.D. Kitts, F. Newsome, and G.H.N. Towers. 1982. Anti-reproductive and other medicinal effects of Tropaeolum tuberosum. J. Ethnopharmocology 5(2):149-161.

Johns, T. and G.H.N. Towers. 1981. Isothiocyanates and thioureas in enzyme hydrolysates of Tropaeolum tuberosum. Phytochemistry 20: 2687-2689.

King, S.R. 1987. Four endemic Andean tuber crops: promising food resources for agricultural diversification. Mountain Res. and Devel. 7(1):43-52.

King, S.E. and S.N. Gershoff. 1987. Nutritional evaluation of three underexploited Andean tubers: Oxalis tuberosum (Oxalidaceae), Ullucus tuberosus (Brasellaceae), and Tropaeolum tuberosum (Tropaeolaceae). Econ. Bot. 41(4): 503-511.

Larson, R.A., K.A. Marley, R.W.Tuveson, and M.R. Berenbaum. 1988. $\beta$-Carboline alkaloids: Mechanisms of phototoxicity to bacteria and insects. Phytochem. Photobiol. 48:665-674.

Leon, J. 1964. The "maca" (Lepidium meyenii), a little-known food plant of Peru. Econ. Bot. 18(2):122-127.

Montaldo, A. 1977. Cultivo de raices y tuberculos tropicales, p. 284. IICA, San José, Costa Rica.

Montenegro, L.F. and S. Franco.1988. Evaluacion de nutrientes en tre variedades de Mirabilis expansa (chango). Instituto de Estudios de Bromatologia y Nutricion Andina, Lima-Peru.

Moore, M. 1988. Medicinal plants of the mountain west, p. 104. Museum of New Mexico Press, Santa Fe.

National Research Council. 1989. Lost crops of the Incas. Natl. Academy Press, Washington, D.C., p. 1-123.

Pintão, A.M., M.S.S. Pais, H. Coley, L.R. Kelland, and I.R. Judson 1995. In vitro and in vivo antitumor activity of benzyl isothiocyanate: Anatural product from Tropaeolum majus. Plant Med. 61: 233-236.

Pulgar-Vidal, J. 1981. Geografía del Perú: Las ocho regiones naturales del Perú, Ed 7. Editorial Universo S.A., Lima, Peru.

Quiros, C.F.,A.Epperson, J.Hu, and M. Holle, 1996. Physiological and cytological characterization of maca, Lepidium meyenii Walp. Econ. Bot. 50:216-223.

Rea, J. 1992. Raices andinas: Maca, p. 163-166. In: J.E. Hernandez Bermejo and J.E. Leon (eds.). Cultivos marginados, otra perspectiva de 1492. FAO, Rome. 
Rea, J. and J. Leon. 1965. La mauka (Mirabilis expansa) un aporte de la agricultura prehispanica de Bolivia, p. 38-41. In: Abales Cientificos de la Universidad Agraria La Molina, Lima.

Sanchez Leon, A. 1996. Que Rica Maca! Somos 495:34-36.

Seminario, J. 1988. El chago mauka (Mirabilis expansa) en Cajamarca, p. 251-264. In: Anales del VICongreso Internacional de Cultivos Andinos, Quito, INIAP.

Seminario, J. and A. Seminario. 1995. Coleccion de germoplasm regional de raices andinas. Boletin de Lima 98:27-47.

Sperling, C.R. 1987. Systematics of the Basellaceae. PhD Diss., Dept. of Organism and Evolutionary Biology, Harvard Univ., Cambridge, Mass.

Sperling, C.R. and S.R. King. 1990. Andean tuber crops: Worldwide potential, p. 428-435. In: J. Janick and J.E. Simon (eds.). Advances in new crops. Timber Press, Portland.

Talalay, P. and J.W. Fahey. 2001. Phytochemicals from cruciferous plants protect against cancer by modulating carcinogen metabolism. J. Nutr. 11:3027S-3033S

Tapia, M.E. 1993. Semillas Andinas: El banco de oro, p. 76. Consejo Nacional de Ciencia y Tecnologia (concytec), Lima, Peru.

Tello, J., M. Hermann, and A. Calderon. 1992. La maca (Lepidium Meyenii Walp.): Cultivo alimenticio potencial para las Zonas Altoandinas. Boletin de Lima 81:59-66.

Torres, O.M., M. Perea-Dallos, and T.J. Fandino. 1992. Micropropagation of Cubio (Tropaeolum tuberosum). Biotechnol. Agr. For. Berlin 19:160-171.

Tripathi, S.M. and D.K. Singh. 2000. Molluscicidal activity of Punica granatum bark and Canna indica root. Braz. J. Med. Biol. Res. 33(11): 1351-1355.

Ugent, D., S. Pozorski, and T. Pozorski. 1984. New evidence for ancient cultivation of Canna edulis in Peru. Econ. Bot.

Vega, C.P. 1997. Cultivo de Olluco, p.38-41. IX Congreso Internacional de Cultivos Andinos, Cusco, Peru.
Vivanco, J.M. and H.E. Flores. 2000. Control of root formation by plant growth regulators, $\mathrm{p}$. 1-25. In: A.S. Basra (ed.). Plant growth regulators in agriculture and horticulture: Their role and commercial uses. Food Products Press, an imprint of The Haworth Press, New York.

Vivanco, J.M., L.F. Salazar, and M. Querci. 1999a. Antiviral and antiviroid activity of MAP-containing extracts from Mirabilis jalapa roots. Plant Dis. 83 (12):1116-1121.

Vivanco, J.M., B.J. Savary, and H.E.Flores. 1999b. Characterization of two novel type I ribosomeinactivating proteins from the storage roots of the Andean crop Mirabilis expansa. Plant Physiol. 119(4):1447-56.

Wielanek, M. and H. Urbanek. 1999. Glucotropaeolin and myrosinase production in hairy root cultures of Tropaeolum majus. Plant Cell, Tissue and Organ Culture 57:39-45.

Zela, G.M., H.C. Bravo, G. Zela, and V. Gonza. 1997. Cultivo de la maswa. IX Congreso Internacional de Cultivos Andinos, Cusco, Peru, p. $42-51$. 